WP/06/38

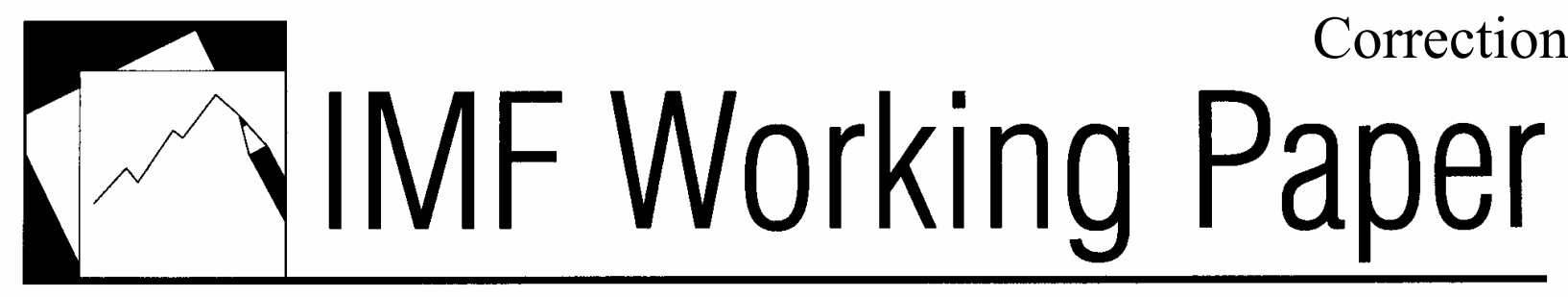

\title{
Providing Official Statistics for the Common Market and Monetary Union in the Gulf Cooperation Council (GCC) Countries-A Case for "Gulfstat"
}

Abdulrahman K.L. Al-Mansouri and

Claudia Dziobek 

(C) 2006 International Monetary Fund

$\mathrm{WP} / 06 / 38$

Correction

\title{
IMF Working Paper
}

Statistics Department

\section{Providing Official Statistics for the Common Market and Monetary Union in the Gulf Cooperation Council (GCC) Countries-A Case for "Gulfstat"}

\author{
Prepared by Abdulrahman K.L. Al-Mansouri and Claudia Dziobek ${ }^{1}$
}

February 2006

\begin{abstract}
This Working Paper should not be reported as representing the views of the IMF. The views expressed in this Working Paper are those of the author(s) and do not necessarily represent those of the IMF or IMF policy. Working Papers describe research in progress by the author(s) and are published to elicit comments and to further debate.

The six member states of the Gulf Cooperation Council (GCC)—Bahrain, Kuwait, Oman, Qatar, Saudi Arabia, and United Arab Emirates (UAE) - have laid out a path to a common market by 2007 and monetary union by 2010, based on economic convergence. To monitor convergence and support economic and monetary policy, comparable economic data for member countries and data for the region as a whole will be essential. What is the most efficient way to produce these data? The authors survey the statistical institutions in the GCC countries and present the case for creating "Gulfstat"-a regional statistical agency to operate within a "Gulf States System of Statistics." Valuable lessons can be learned from regional statistical organization in Africa and the European Union-Afristat and Eurostat.
\end{abstract}

JEL Classification Numbers: H11, R10, E6

Keywords: Data Quality, Regional Economic Integration, Gulf Cooperation Council

Author(s) E-Mail Address: aebrahem@mop.gov.kw and cdziobek@imf.org

\footnotetext{
${ }^{1}$ The authors are, respectively, Assistant Undersecretary Statistics and Census Sector at the Kuwait Ministry of Planning and Advisor in the IMF Statistics Department. The authors gratefully acknowledge comments on earlier drafts from Fernando Delgado, Nicole De Windt, Robert Edwards, Rene Fiévet, Dieter Glatzel, Rajan Govil, Artak Harutyunyan, Robert Heath, Russell Krueger, Lucie Laliberté, Ahsan Mansur, Eric Métreau, Anthony Pellechio, Mohamed Omran, Neil Patterson, Kim Zieschang, and from participants of the Statistics Department Seminar discussion.
} 
I. Introduction

II. Data Needs of the Common Market and Monetary Union in the GCC States.....................4

A. Evolving Vision for Joint Statistical Work in the GCC ...........................................5

B. Data Quality Considerations ......................................................................

III. The Institutional Setting for Producing Statistics in GCC Countries .............................8

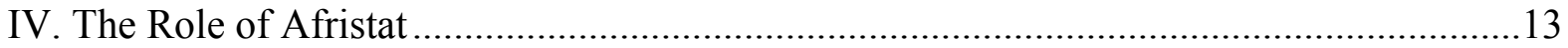

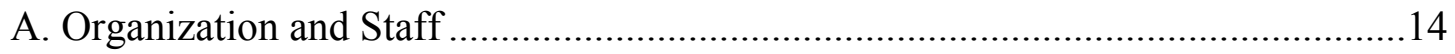

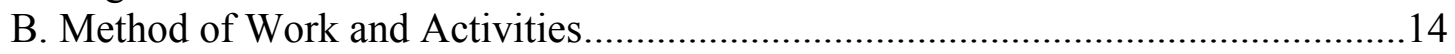

C. Some Accomplishments of Afristat ........................................................... 16

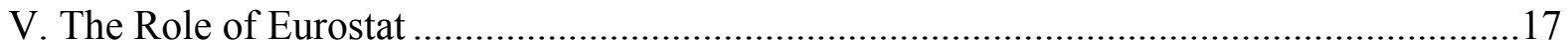

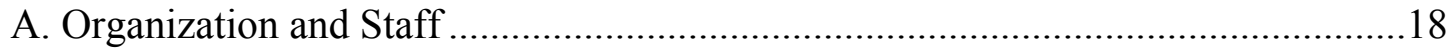

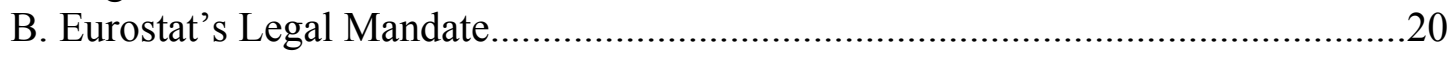

VI. Key Lessons for a Future Gulfstat ..........................................................................22

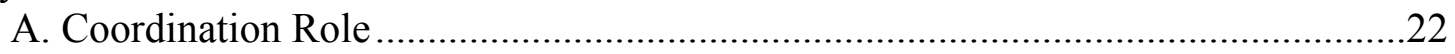

B. Roles of National Statistical Offices, including for Government Finance

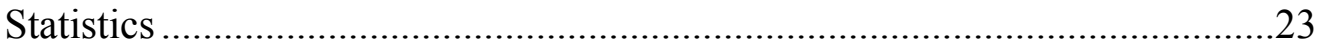

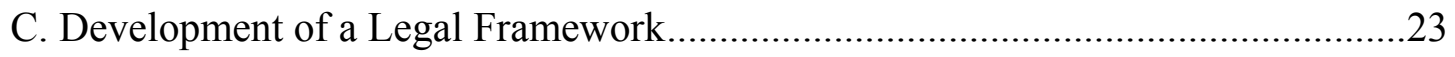

D. Producer of Regional Data ............................................................................24

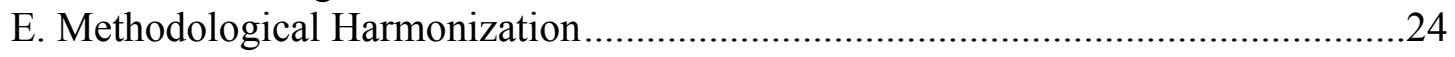

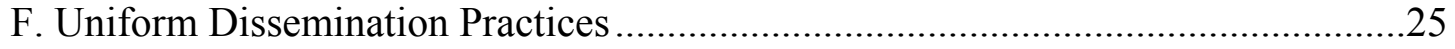

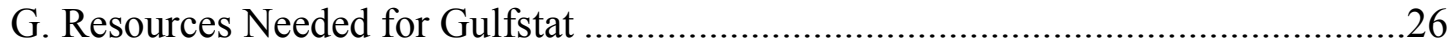

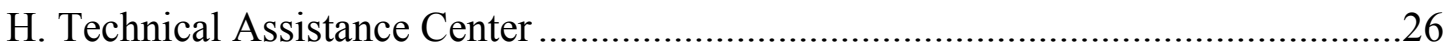

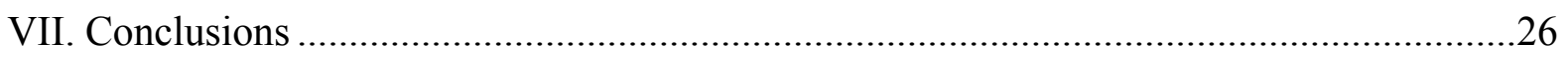

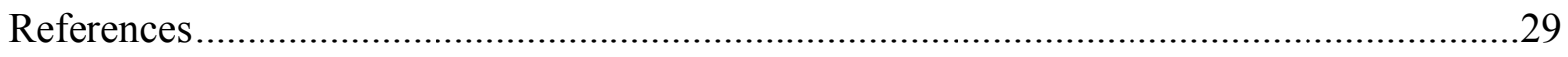

Tables

1. Data Transparency: GDDS/SDDS Membership of Afristat and Eurostat Member

Countries Compared with Gulf Cooperation Council (GCC) Countries .......................7

2. The IMF's Data Quality Assessment Framework (DQAF) Provides Guidance on

Good Practices in Statistics and Good Governance of Statistical Agencies..................7

3. Institutional Setting of Statistical Production in the GCC States (August 2005) ...............10

4. Afristat and Eurostat Support Economic Regions beyond Monetary Unions ...................25

Box

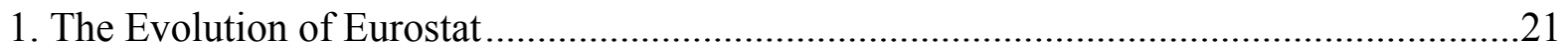

Appendix Table

A.1. Gulf Cooperation Council States-Selected Economic Indicators...............................28 


\section{INTRODUCTION}

A common market by 2007 and a monetary union by 2010 are policy goals set by the members of the Gulf Cooperation Council (GCC). While these goals are ambitious, the economic conditions for achieving them are favorable, given the environment of high oil prices, economic growth, and relative economic stability.

Good-quality statistics are needed to support a single economic and monetary policy framework, as is increasingly recognized in the literature (Bull, 2004; Fasano and Iqbal, 2002; Fellegi and Ryten, 2005; Ocampos 2005). This will involve broadly harmonizing the statistical standards at the national level, as well as developing new regional statistics. Both are closely related, however, because regional statistics, to a large extent, build on national statistics. What is the best way to organize the harmonization and regional integration of data? At a recent meeting of the ministers of finance and governors of the Cooperation Council of the Arab States of the Gulf, the IMF Managing Director Rodrigo de Rato suggested that, learning from the experience of Europe, an institution perhaps along the lines of Eurostat in the European Union (EU) would provide the GCC authorities with high-quality statistical information (IMF, 2004).

Coordination of statistical activity to achieve cross-country comparability has already been ongoing in the Gulf States for some time, particularly in the form of biannual meetings of the heads of statistical agencies. This group is developing a common vision, and each country is making an effort to bring key economic indicators up to international standards, which should contribute to greater comparability. In this context, the purchasing power parity (PPP) data, generated by the International Comparison Program for the six GCC countries, are a valuable tool for monitoring of economic convergence. In addition, the GCC Secretariat publishes a statistical bulletin - a starting point for a regional program of data dissemination.

The heads of the statistical agencies are also developing initiatives for regional statistics. Producing data for the group of six countries as a whole requires considerable preparation and in some cases adjustments in the way national agencies collect data. The mere aggregation of data, in most cases, is not sufficient to provide a picture of the region as a whole. Recognizing this, the heads of national statistical offices of the six countries agreed in April 2005 to intensify the program of statistical coordination and to consider in particular the institutional structure of statistics serving the monetary union. In principle, the heads have agreed to conduct a regionally coordinated household survey in 2006 and a population census in 2010. The survey and the census will provide source data for regional economic statistics.

Against the background of these developments, the authors explore the case for establishing a regional system of statistics, composed of national statistical agencies and a regional agency. A regional agency would provide statistical services, including coordination of regional statistics and statistical activity. Merits, challenges, and modalities of setting up such an agency are discussed against the background of Afristat and Eurostat - two other regional 
statistical agencies. The proposed new agency is referred to as "Gulfstat" in the remainder of this paper.

In Section II, we review the data needs of the common market and a monetary union. In Section III, we describe current institutional arrangements for data production in each Gulf State; the discussion is based on a questionnaire sent to the statistical agencies of the GCC countries. Sections IV and V highlight key functions and roles of Afristat and Eurostat, respectively. Section VI lays out key lessons, learned from both agencies, for Gulfstat - a possible regional statistical agency for the GCC states. Conclusions are drawn in section VII.

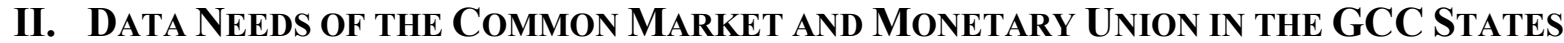

The overall aim of the GCC is to bring about integration of its member states (GCC, 1981). Progress in economic integration can be measured against a set of criteria, including convergence of macroeconomic indicators, trade patterns, and social trends (Fasano and Iqbal, 2002; Appendix Table 1 provides selected indicators of the GCC countries). For monetary union, specific convergence criteria would need to be identified to guide the process towards a single currency. No official announcement has yet been made in this regard, but current discussions focus on convergence criteria similar to those adopted in Europe as part of the Maastricht Treaty of 1992: inflation, interest rates, foreign exchange reserves, fiscal deficit, and debt relative to gross domestic product (Jadresic, 2002, discusses the economics of a common currency for the GCC countries).

The required datasets could be divided into those supporting the common market and those supporting the monetary union, although in practice, a large overlap exists. Following a review of the data that would need to be available on a regional basis, the GCC national statistical agencies have identified the following list of core data required for regional monitoring and policy support:

- national income and expenditure accounts statistics,

- $\quad$ price data (consumer price index, producer price index, export and import indices),

- balance of payments statistics,

- $\quad$ foreign trade (value, quantity, geographical distribution, intra-GCC trade),

- government finance statistics,

- agricultural statistics,

- $\quad$ internal trade and services,

- unemployment data,

- labor statistics,

- $\quad$ oil and gas statistics,

- $\quad$ monetary and financial statistics, and

- $\quad$ information on trade barriers, including on customs.

These data requirements are akin to those of Afristat and Eurostat. Afristat identifies the following datasets in its mission statement (Afristat, 2005): national accounts, input-output 
tables, government finance statistics, price statistics, agricultural and household surveys, social statistics, poverty statistics, and information statistics (Trade and labor statistics are not explicitly mentioned). Similarly, Eurostat covers the following broad areas (listed by directorate): national and European accounts, including government finance statistics; economic and regional statistics, including price statistics and short-term indicators; agriculture and environment statistics; social statistics and information statistics, including labor market statistics; and business statistics, including trade, energy, and transport (Krueger and Kovarich, 2006).

Producing such data for the region as a whole involves more than a mere aggregation of national data. An obvious case in point is balance of payments statistics, where transactions among the GCC countries would need to be netted out to produce meaningful statistics. For example, the residency criterion, which is central for balance of payments statistics, would have a different application depending on whether residency is defined nationally or on a region level. Accordingly, data collection would need to be adapted. Another example is regional price statistics, which require information about regional consumption patterns not necessarily reflected in each national price index (Astin, 1999; Bull, 2004).

\section{A. Evolving Vision for Joint Statistical Work in the GCC}

The heads of national statistical offices of the GCC states meet regularly to discuss issues of common concern. For some time, these meetings have focused on the statistical requirements of both the common market and a monetary union. In May 2004, the heads of GCC national statistical offices adopted, in their seventeenth meeting, a vision of measures to consolidate and further develop joint statistical work in the GCC (SCS, 2004). The set of recommendations covers the following measures:

- $\quad$ Emphasize unification of statistics laws in the GCC member countries.

- $\quad$ Adopt a common methodology in building a data warehouse containing a broad base of comparable data on demographic, social, and economic profiles of the GCC countries.

- $\quad$ Conduct a series of specialized demographic sample surveys on specified dates to fill gaps in population statistics.

- Improve human development statistics and indicators.

- Unify classifications of foreign trade statistics.

- Undertake joint field research at the GCC level to address urgent policy issues, prior to formation of a common market and monetary union. These issues relate to labor market (employment and unemployment), industrial development, and foreign trade policies. 
- Coordinate and cooperate in building and networking special statistical databases on foreign direct investment.

- Cooperate in implementing statistical requirements of the International Comparison Program (ICP).

- Coordinate and cooperate in compiling and processing gender statistics, which would, among other purposes, monitor implementation of the Millennium Development Goals (MDGs).

In 2005, the heads of the national statistical offices of the six countries agreed to intensify the program of statistical coordination and to consider in particular the institutional structure of statistics serving the monetary union. In principle, the heads of national statistical agencies have agreed on conducting a regionally coordinated household survey in 2006 and a population census in 2010 . The regional household survey will provide information on consumption patterns and disposable income. This, in turn, will feed into compound datasets, such as the national accounts, and will set appropriate weights for a harmonized price indicator.

\section{B. Data Quality Considerations}

Comparability of data is a key requirement of statistical information, and this requires adopting common methodologies in compiling, processing, and disseminating data. That is, each national agency needs to use common (international) standards and accounting frameworks to compile regional data. Under the current institutional framework, data are either not comparable or not available. Where data are available, agencies cannot easily assemble data for the GCC countries as a group. While national statistical offices are responsible for producing most statistics, either exclusively or in collaboration with other agencies, some do not produce the datasets traditionally generated by national statistical offices - for example, national accounts data or price statistics. As a result, creating coordination mechanisms to foster effective collaboration would be a complex task. In some instances, reorganization of responsibilities may be more effective.

The IMF data standards initiative could play a useful supporting role in data comparability. The General Data Dissemination System (GDDS) contains a tool for diagnosing current practices in each country and provides a guided path toward a strategic plan for moving toward harmonized standards. The standards referred to in the GDDS build on the UN Fundamental Principles of Statistics and they reflect best international statistical practices. The GDDS allows countries to describe their current practices (metadata) to compare them with the best international practices. In a separate "plan for improvement" column, countries describe the steps they intend to take to move toward international standards. The GDDS can thus play an important role in helping each national statistical agency put in place global standards (Carson and Laliberté, 2002a and 2002b; UN, 1994 and 2003). 


\begin{tabular}{|l|l|l|l|l|l|}
\hline \multicolumn{6}{|c|}{$\begin{array}{l}\text { Table 1. Data Transparency: GDDS/SDDS Membership of Afristat and Eurostat Member } \\
\text { Countries Compared with Gulf Cooperation Council (GCC) Countries }\end{array}$} \\
\hline Regional Agency & $\begin{array}{l}\text { No. of } \\
\text { Countries }\end{array}$ & SDDS & GDDS & $\begin{array}{l}\text { Percent } \\
\text { SDDS/GDDS }\end{array}$ & $\begin{array}{l}\text { No. of Countries with Data } \\
\text { ROSC Reports }\end{array}$ \\
\hline Afristat & 18 & 0 & 16 & 88 & 14 \\
\hline Eurostat & 28 & 25 & 2 & 96 & 17 \\
\hline GCC & 6 & 0 & 3 & 50 & 1 \\
\hline
\end{tabular}

Source: www.dssb.imf.org

Notes: GDDS=General Data Dissemination System; SDDS=Special Data Dissemination Standard. ROSC $=$ Report on the Observance of Standards and Codes.

Another useful feature of the GDDS is that it helps the coordinating process because it allows countries to compare statistical practices. This tool will prove particularly helpful in an environment where countries may be continuously upgrading practices and where statisticians who are engaged in regional cooperation will need to monitor progress in harmonizing data across countries. Conversely, as change will not be instant, statisticians will frequently be called upon to explain differences in the data published by each country. The GDDS web-based database of each country's metadata will provide insights into such matters. In this way, participation in GDDS would provide a solid inventory of information about statistical practices in the region, it could form a basis for the work of a regional statistical agency (Gulfstat).

The GDDS also guides participants on legal and institutional requirements of good practices along the lines of the IMF's Data Quality Assessment Framework (Table 2), which lays out and describes in detail a set of quality dimensions (UN, 2003; Kawaja and Morrison, 2002).

\begin{tabular}{|l|l|}
\hline $\begin{array}{r}\text { Table 2. The IMF's Data Quality Assessment } \\
\text { Good Practices in Statistics and Good Gowork (DQAF) Provides Guidance on }\end{array}$ \\
\hline Dimension & Some of the key elements \\
\hline Prerequisites of quality & Legal, institutional environment, resources \\
\hline Assurances of integrity & Professionalism, transparency, ethical standards \\
\hline Methodological soundness & Concepts, definitions, classifications \\
\hline Accuracy and reliability & Source data, statistical techniques \\
\hline Serviceability & Periodicity, timeliness, consistency, revisions \\
\hline Accessibility & Data accessibility, assistance to users \\
\hline
\end{tabular}

Source: IMF Data Quality Assessment Framework; http://dsbb.imf.org (go to DQRS). The website contains the full documents which provide detail for major macroeconomic datasets.

The DQAF has been applied in a number of contexts, including in countries' selfassessments and in planning statistical reforms. GDDS tables are arranged using this framework, which could help guide GCC countries in further developing their plans as laid out in the vision statement (Carson and Laliberté, 2002a; Carson, Khawaja, and Morrison, 2004; Dziobek and Mei, 2002). The IMF has prepared more than 80 data Reports on the Observance of Standards and Codes (ROSCs), which are comprehensive studies of country 
practices, using the Data Quality Assessment Framework. ROSCs are published on the IMF's website and they are an important source of information about good (and deficient) practices in statistics, providing a wealth of information for countries in the process of capacity building.

Kuwait, Oman, and Qatar participate in the GDDS, and the three other GCC countries are in the process of joining. Oman has recently published its data ROSC (http://dsbb.imf.org/). Over time, all other Gulf States could participate in the data ROSC and could subscribe to the Special Data Dissemination Standard (SDDS), which would further raise the level of data quality and cross-country comparability and support capital market development (Cady, 2004).

\section{The Institutional Setting for Producing Statistics in GCC Countries}

Producing, across countries, comparable data that can be aggregated or consolidated into regional data entails close coordination among data-producing agencies. Having clearly assigned responsibilities in each country is an important building block in this regard. As background, the authors conducted an informal survey to establish an overview of the current institutional arrangements in the GCC countries (Table 3).

For monetary and balance of payments statistics, central banks have the lead responsibility in all but one country. For balance of payments statistics, statistical agencies could provide significant input in areas where they have a comparable technical advantage, for instance, expertise in conducting surveys. Concerning data on foreign direct investment, a statistical agency that has experience with survey design and execution could conduct surveys most efficiently (Bull, 2004). ${ }^{2}$

Government finance statistics are the responsibility of the finance ministries, which, in principle, should facilitate coordination across countries. However, bringing fiscal data to international standards and harmonizing definitions across GCC countries so that these data can support the monitoring of convergence presents a special challenge, which will require an appropriate institutional arrangement. ${ }^{3}$ An important task will be to clearly define the legal responsibility for compiling and disseminating government finance statistics in the context of monetary union. In the EU countries, and in many other industrial countries, government finance statistics are generally the responsibility of national statistical agencies. Ministries of finance produce much of the source data but responsibility for compiling and disseminating

${ }^{2}$ In Europe, balance of payments statistics are the shared responsibility of the European Central Bank (ECB) and Eurostat and a memorandum of understanding specifies the details of the cooperation (ECB, 2003).

${ }^{3}$ IMF (2002) presents case studies, including 14 EU countries, and it illustrates the application of the new Government Finance Statistics Manual 2001 (GFSM 2001). 
these data lies with the national statistical agency. A similar approach might be considered for the GCC countries.

Concerning all other statistics, the institutional structure is far more complex, involving a large number of agencies. As shown in Table 3, statistical production in the GCC states involves many different agencies in each country, not only producing different sets of data but, in some cases, producing the same set of data, such as national accounts, and statistics on prices, foreign trade, labor and unemployment, and energy.

The large number of agencies, by itself, puts forward a case for establishing Gulfstat to promote and facilitate appropriate coordination. The agency could coordinate between various statistical agencies in harmonizing concepts and classifications and adopting a common methodology in the statistical work, so as to make statistics comparable.

Saudi Arabia's statistical structure follows a relatively standard approach, with a national statistical agency responsible for the core economic datasets (national accounts, prices, trade, unemployment, population). Similar arrangements exist in many industrial countries, especially those assessed in the context of IMF standards and codes as having strong statistical qualities (see data ROSCs). In Kuwait, Oman, and Qatar, national statistical agencies also perform central functions, but they operate from within national ministries (Planning and National Economy) rather than as independent entities. A statistical agency within a line ministry may be perceived as lacking statistical independence. In this respect, a study of integrity of statistical agencies along the lines of the IMF Data Quality Assessment Framework (DQAF) might be a useful exercise. Moreover, it may be necessary to develop special arrangements that allow statistical agencies to enter into agreements across GCC countries or with a regional statistical agency. In Bahrain and UAE, statistical activity is relatively dispersed, involving a number of agencies. Consultation mechanisms and cooperation would benefit from simpler and more transparent institutional settings. 


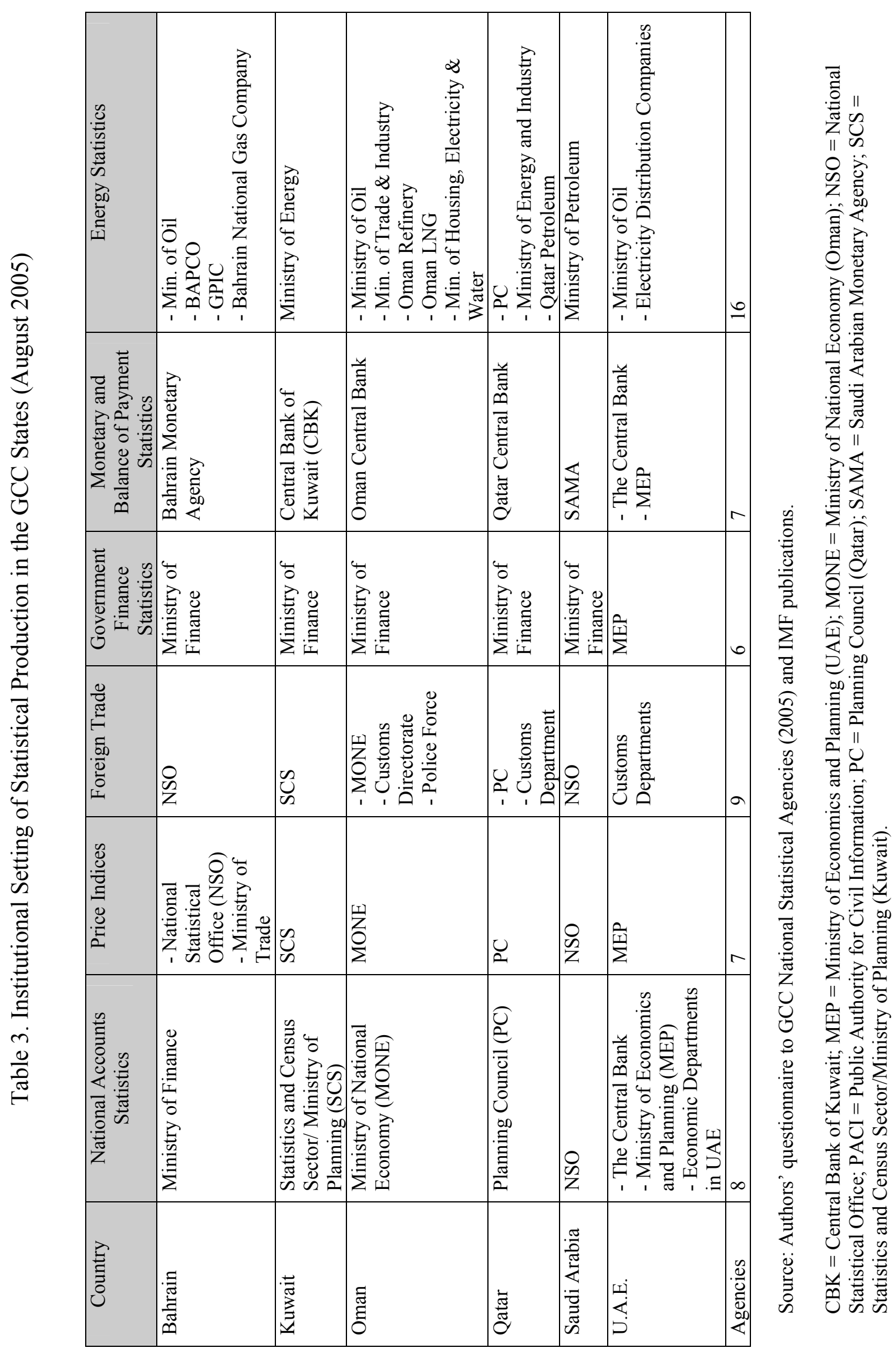




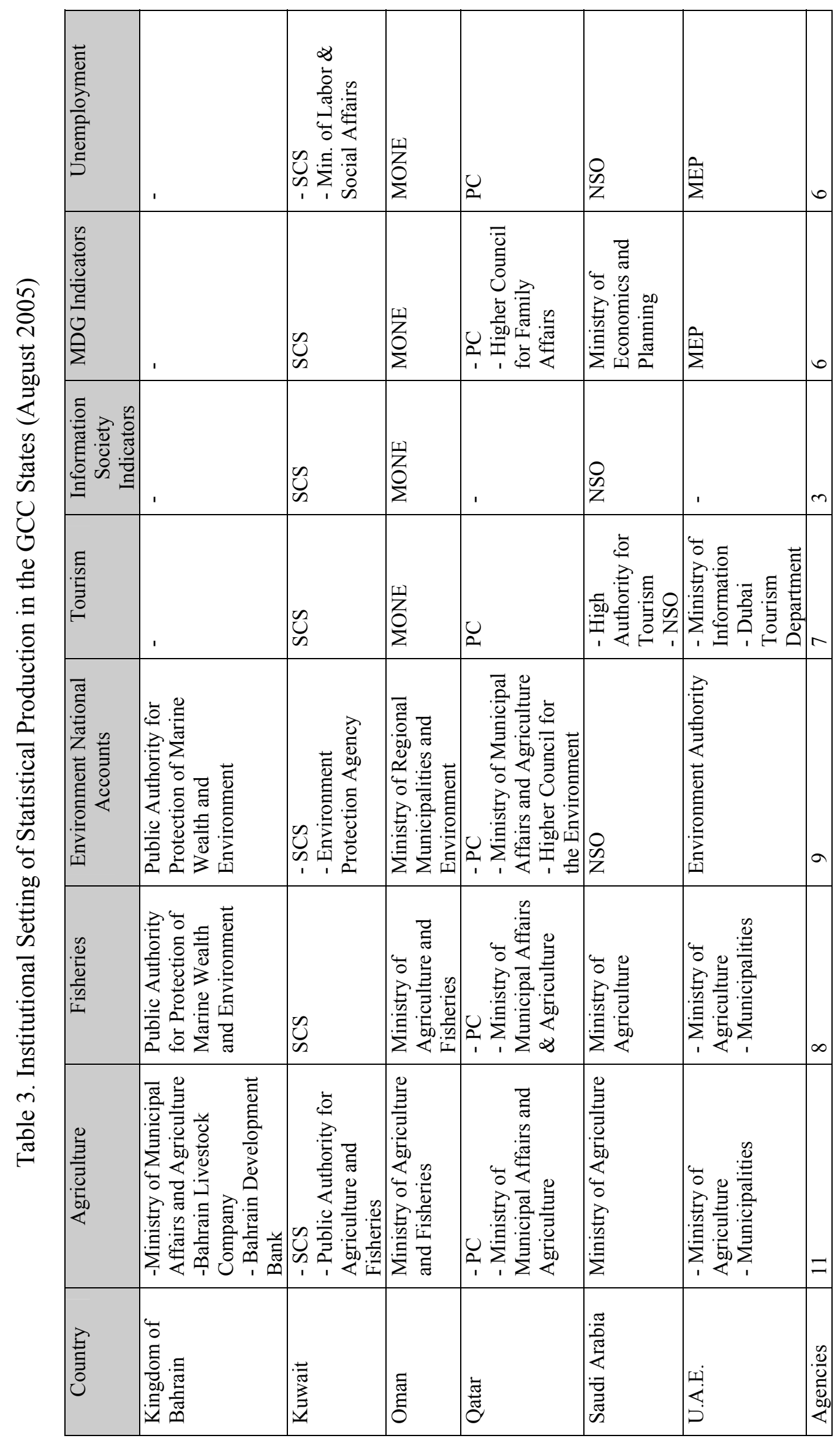




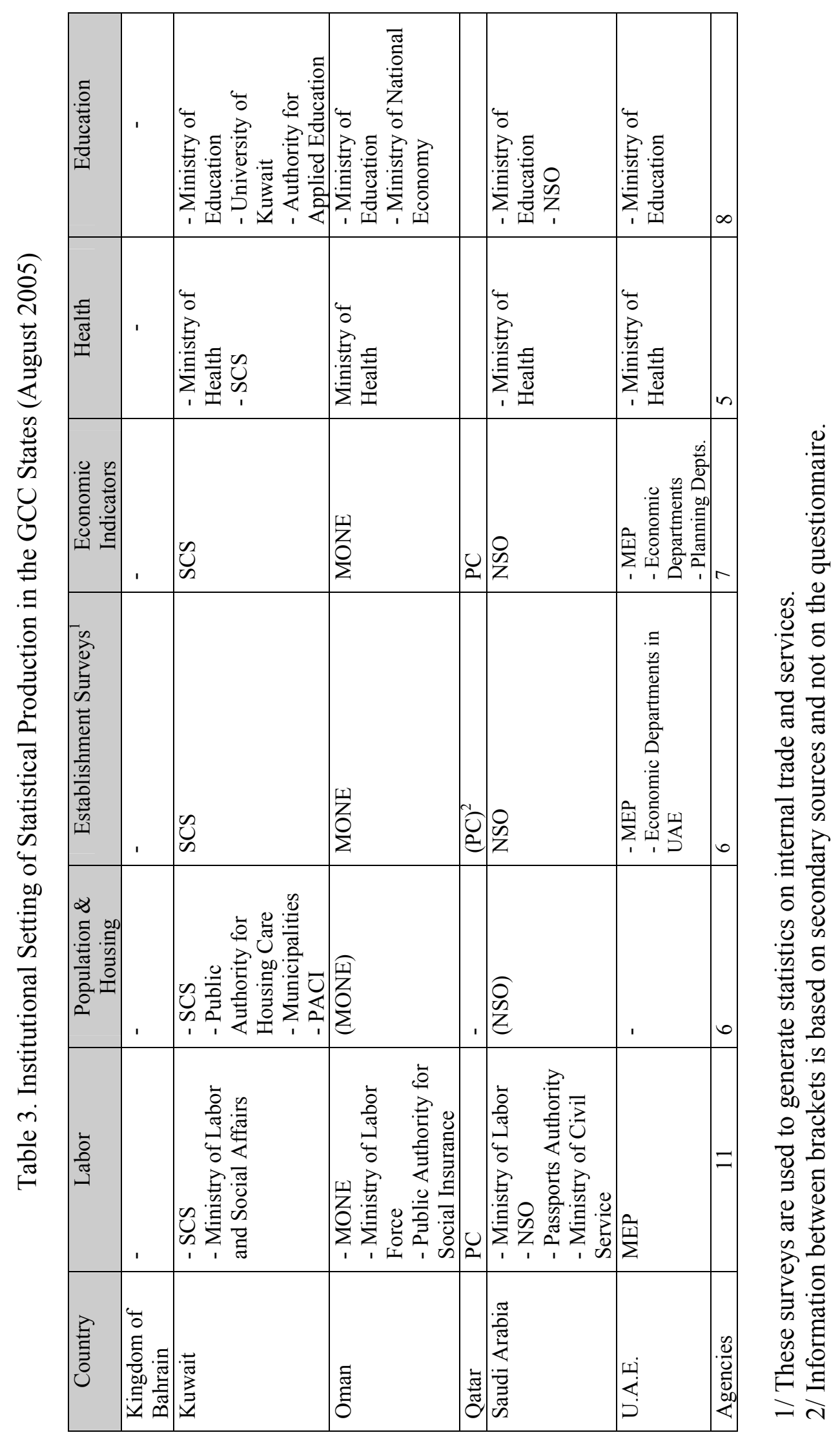


An appropriate institutional framework needs support of a legal structure. An adequate legal structure should include the backing of a law that gives the national statistical agency in each country takes lead responsibility for official statistics (Fellegi, 1996; Khawaja and Morrison, 2002). In many countries, including most industrial and emerging countries, one independent central statistical agency is the major source of official statistics. This agency is also responsible for coordinating the overall statistical program. In building a regional statistical system for the GCC countries, a review of current legal arrangements would provide a useful starting point.

An effective regional statistical agency (Gulfstat) would require a clear legal mandate to support GCC integration and it would have to be vested with the necessary professional independence. It would need a mandate to collect and disseminate data on economic integration. However, a regional statistical agency would not replace national statistical agencies; rather its main task would be to lead the process of harmonizing data standards of the GCC countries. Examples of solid legal structure can be found in the data ROSC country reports. These reports are available on the IMF website and they provide detailed information and assessments of national statistical systems' legal and institutional environments (about 70 such reports are available).

A strong legal structure has a particular importance in the context of building a common market and monetary union. Data to monitor the convergence criteria can be perceived as politically sensitive. Therefore, complete impartiality of the statistical processes is central to an effective institutional environment. Conflicts of interest might ensue if the producing agency has a vested interest in the data it produces - for example, for GDP data produced by an agency responsible for managing macroeconomic policy.

\section{The Role OF Afristat ${ }^{4}$}

Afristat is a supranational organization formed to support statistical development in subSaharan Africa comprising 18 countries. It was created by a treaty signed in Abidjan in 1993 by the African members of the franc zone-Burkina Faso, Cameroon, the Central African Republic, Chad, Comoros, Congo, Côte d'Ivoire, Equatorial Guinea, Gabon, Mali, Niger, Senegal, and Togo. In April 1998, Guinea-Bissau and Mauritania joined Afristat, and Cape Verde and Guinea became member states in 2000 and 2002, respectively. Under the terms of Article 5 of the Treaty of Abidjan, any sub-Saharan country and any Indian Ocean country can apply to join Afristat. Its headquarters are in Bamako, Mali, and it started its activities on January 2, 1996. Afristat was created for three main reasons:

- $\quad$ to pool scarce resources to halt the decline of national statistical systems, which was observed throughout the 1980s;

\footnotetext{
${ }^{4}$ This section draws on Afristat (2001) and Afristat (2005).
} 
- $\quad$ to promote the consistency and comparability of statistical information in all the member states, following the political will expressed in the early 1990s for renewing and strengthening the regional integration process; and

- $\quad$ to promote reliable economic and social information, which would be accessible in a timely manner under the best conditions of cost to all the economic and social agents and citizens with a view to strengthening the democratization process.

\section{A. Organization and Staff}

Afristat has a permanent organ - the Directorate General — that is a flexible and small structure composed of the director general and the deputy director general. Initially, it had 10 experts appointed for a period of six years: two national accountants; one price statistician; one expert in household surveys; two statisticians expert in data processing and computers; one macroeconomist; one economist specialized in the informal sector, employment, and poverty; one agricultural statistician; and one expert in enterprise statistics. Afristat receives support from the French government and it collaborates with the World Bank and with other donors. The structure of Afristat is evolving with changing needs, and the number of staff has been changing, reflecting new priorities (e.g., poverty statistics were added) and available funding. It was first funded for a period of 10 years and was recently refunded for an additional 10-year term (until 2015). Work priorities were reviewed and adjusted to reflect evolving needs.

The director general and the deputy director general are experts in the organization of national statistical systems and training. Ten locally recruited staff assist this team. In addition to the office of the director general, several administrative and financial units and three departments - each headed by a coordinator — constitute the Afristat Directorate General. The three departments are Surveys and Statistics; Analytical Studies and Economic Reviews; and Data Processing, Documentation, and Publications.

\section{B. Method of Work and Activities}

Afristat's objective is to build sustainable statistical capacity in member states for producing economic and social information. Afristat promotes regional integration of statistics and macroeconomic analysis. Its actions support the national statistical systems (particularly the national statistical offices, or NSOs), and its approach is based on coordinating and harmonizing concepts, standards, methods, and sources. The general work method covers:

- technical assistance and training;

- $\quad$ developing statistical systems to support poverty reduction strategies and MDGs;

- $\quad$ helping member countries strengthen capacity to collect, compile, and analyze statistics;

- $\quad$ helping countries develop data warehouse and the capacity to disseminate data; and 
- $\quad$ fostering international methodologies adapted to countries' capacity.

Afristat has identified a set of priority activities to achieve specific objectives. These activities include the following:

\section{Institutional capacity building}

Institutional capacity building consists of building managerial capacities (particularly in the NSO) through training and sensitization; defining a regionally coordinated strategic framework for sustainable development of the national statistical systems; and supporting development of national statistical programs tailored to their specific needs.

\section{National accounts}

For national accounts statistics, Afristat assists member states implement the System of National Accounts 1993 (1993 SNA). To ensure comparability of national accounts data, member states decided to develop a common methodological base for compiling national accounts. Provisional and estimated accounts can be disseminated on this common base. The accounts should also produce results consistent with the GDDS - field of data application, frequency, timeliness and periodicity of data dissemination, quality, integrity, and access to the public.

\section{Classifications}

Comparability of statistical data within Afristat member states requires the use of common classifications. Afristat began to study the extent to which the main classifications used in compiling the statistics could be harmonized. To ensure comparability at the regional and global level, the member states use the classifications developed in the UN and its various agencies.

\section{Price statistics and household surveys}

Afristat combines assistance on price statistics and households surveys to establish a harmonized consumer price index (CPI) in member states. The availability of timely price data is given a high priority because of the important role of the CPI for many policy decisions, including monetary policy. Within the context of economic and monetary integration, harmonized price statistics are extremely useful for multilateral coordination and surveillance of economic policies. Afristat's role is to help statistical agencies collect, process, and analyze data concerning prices and household surveys. Afristat also provides training of the NSO executives to manage new techniques.

\section{Enterprise statistics}

Enterprise statistics are important for monitoring economic activity (particularly for shortterm economic trends) and are needed for national accounts statistics. A proper information system on enterprises should use, ideally, not only administrative sources (tax records with 
statistical annexes) but also structural surveys (industrial surveys, sampling surveys) and economic situation surveys (industrial production, opinions of heads of enterprises, etc.).

\section{Computer activities and data processing}

The general objectives of Afristat in data processing are:

- $\quad$ to design a common methodology for collecting and processing basic statistical information;

- to improve the dissemination and use of statistical information in all member states, particularly by developing databases accessible to economic and social agents in the region; and

- $\quad$ to provide support to the activities of NSOs of member states in the field, particularly through training.

\section{Documentation and data dissemination}

Making data available for public use is one of Afristat's objectives. Regarding documents, assistance to member states is provided for modern storage and dissemination facilities for statistical and economic documentation. Regarding dissemination, the general objective is to promote use of new information and communication technologies, helping ensure easy access to economic and social information by the economic and social agents and the citizens.

\section{Macroeconomics and analysis of the current economic context}

The objective is to assist the NSOs in designing and disseminating regular information on the economy, analyzing the short-term projection, and, where necessary, using an adapted model for analyzing the economy of each country.

\section{Some Accomplishments of Afristat}

Afristat has helped NSOs break out of a position of isolation. Senior officials and technical staff in national statistical agencies now have fruitful contacts with colleagues from other countries through exchange of experiences and brainstorming in frequent meetings. Technical support provided by Afristat experts to their national counterparts contributes to know-how and to managerial capacities.

With the Common Minimum Statistical Programme (PROSMIC), ${ }^{5}$ member states obtained a strategic framework for developing statistics, which is sufficiently flexible to allow

\footnotetext{
${ }^{5}$ PROSMIC is the reference framework for the development of statistics in member states during the 2001-05 (five-year) period. It covers six priority fields: statistical coordination;
} 
adaptation for country-specific needs. The basis for the harmonization and the comparability of statistics was established with the design of common activity and product classifications, design of a common methodological base for national accounts, and use of other common tools. Also, common concepts for surveys on employment and the informal sector were developed. A common methodology and tools for designing the CPIs were developed. Methodological guides in prices and national accounts were set up, and the improved dissemination of statistical information was facilitated by use of new technologies, Internet, CD-ROM, and others means.

\section{THE Role OF EURostat ${ }^{6}$}

The EU and the European Monetary Union (EMU) are successful examples of regional cooperation. The European statistical system, including Eurostat as the regional statistical agency, has evolved over several decades, and its experience contains many valuable insights for other regional groups. Eurostat is the Statistical Office of the European Communities, situated in Luxembourg. Eurostat was established in 1953 to meet the requirements of the Coal and Steel Community. Over the years, its task broadened when the European Community was founded in 1957 (see Box 1). Its key role is to supply the Economic Commission and other European institutions with data so that they can define, implement, and analyze Community policies. Since the start of EMU, the ECB also became an important user of statistics produced by Eurostat.

Eurostat's main role is to process and publish comparable statistical information at the European level and the goal is to arrive at a common statistical "language" that embraces concepts, methods, structures, and technical standards. Collecting data remains largely the responsibility of member states and their statistical authorities, as does verifying and analyzing the national data. Eurostat's role is to consolidate the data and ensure they are comparable, using harmonized methodology. Data issued are harmonized as far as possible. With the birth of the euro, a need arose to measure the development of the EMU, which has fueled the harmonization of methodology in economic data among member states. ${ }^{7}$ Eurostat now also publishes economic indicators for the whole euro area.

national accounts; economic and social short-term developments; dissemination of statistical information; statistics for monitoring living conditions of households and poverty; and agricultural statistics.

${ }^{6}$ This section draws on the Eurostat website (http://epp.eurostat.cec.eu.int) and Glatzel (2006).

${ }^{7}$ In the context of the Euro area, the Treaty on the European Union assigns the responsibility for providing official economic and financial statistics to both the ECB and Eurostat. Two Council Regulations have been adopted which provide a framework for the statistical activities of the Community and the ECB, respectively, namely Council Regulation (EC) No. 322/97 on Community Statistics and Council Regulation (EC) No. 2533/98 concerning the collection of statistical information by the ECB. The respective areas of responsibility are 
Eurostat cooperates closely with international organizations, such as the UN, IMF, and Organisation for Economic Co-Operation and Development, and also works with a number of countries outside the EU. Another task for Eurostat is to coordinate the improvement of statistical systems in candidate and developing countries. Eurostat's Press Office puts out user-friendly news releases on selected data on the EU and member states and their partners. The Press Office also prepares statistical briefing notes on important EU decisions and events, such as major conferences. These can be used as background to news stories, and TV and radio programs.

\section{A. Organization and Staff}

Eurostat, a Directorate-General of the European Commission, is headed by a director general under whom seven directors serve, responsible for different sectors of Eurostat activities. The European Statistical System (ESS) comprises Eurostat and the statistical offices and agencies, ${ }^{8}$ that collect official statistics in EU member states, Iceland, Norway, and Liechtenstein. Member states collect data and compile statistics for national and EU purposes. The ESS functions as a network in which Eurostat's role is to lead the way in harmonizing statistics in close cooperation with the national statistical authorities. ESS work concentrates mainly on EU policy areas; in addition, with the extension of EU policies, harmonization has been extended to nearly all statistical fields.

detailed in a Memorandum of Understanding, first signed in 1995 and amended in 2003 (http://www.ecb.int/ecb/legal/pdf/en_mou_with_eurostat1.pdf). Its aim is to avoid duplication of statistical work at European Union level, to prevent conflicting requests for data from the ECB and the Community institutions and to promote high-quality statistics for the use of policy-makers, markets, researchers and the public at large. Along these lines, the monetary and financial statistics are within the responsibilities of the ECB, while balance of payments statistics and financial and non-financial accounts are a shared responsibility of the ECB and Eurostat. All other economic statistics fall mainly under the responsibility of Eurostat. The role of the ECB also bears important lessons for the GCC, but is beyond the scope of this paper (Krueger and Kovarich, 2006).

${ }^{8}$ Central banks are not part of the ESS in accordance with Art. 9 of Council Regulation 322/97. It is specifically stated that "The European Monetary Institute... and the national central banks do not participate in the production of Community statistics, by analogy with Article 3 (2) (c), following an agreement between a national central bank and the Community authority within their respective spheres of competence and without prejudice to national arrangements between the national central bank and the national authority, data produced by the central bank may be used, directly or indirectly, by national authorities and the Community authority for the production of Community statistics". 
At the heart of the ESS is the Statistical Programme Committee (SPC), chaired by Eurostat. The SPC brings together the heads of member states' national statistical offices. SPC discusses the most important joint actions and programs to be carried out to meet EU information requirements. It agrees on a five-year program, implemented by the national authorities and monitored by Eurostat. In most cases, demand for new Community statistics comes from the European Commission and the ECB. Eurostat, together with the appropriate Directorate-General, then seeks ways and means of meeting this demand.

The SPC coordinates the following activities:

- development of common classifications, methodology, and definitions for application in member states;

- $\quad$ implementation of common statistical surveys based on harmonized methods; and

- $\quad$ collection, analysis, and dissemination of statistical data for the EU, including comparisons between countries and regions.

A whole series of projects has been implemented over the past few years as a result of fruitful cooperation in numerous working groups of specialists from member states and Eurostat. Some of the projects are as follows:

- $\quad$ The European System of Accounts (ESA): defines the accounting rules and concepts members have to use for reliable analyses and comparison of their economies.

- Intrastat: a new way of measuring trade within the EU after introduction of the single market and abolition of customs formalities at member state borders.

- The Prodcom classification of industrial statistics: the first harmonized nomenclature for products.

- $\quad$ The Community Labor Force Survey and the Harmonized Indices of Consumer Prices: used to measure EU inflation and one of the convergence criteria for countries participating in EMU.

The Committee on Monetary, Financial, and Balance of Payments Statistics (CMFB) is the main mechanism for cooperation between Eurostat, the ECB, member state central banks, the national statistical institutes, and DG ECFIN (Directorate-General for Economic and Financial Affairs) of the European Commission. The CMFB assists and advises the Commission on monetary, financial, and balance of payments statistics. It mainly deals with the definitions of concepts, follow-up, and evaluation of statistical instruments necessary for the EMU. One example of CMFB's work is the opinion it gives on controversial statistical issues concerning the definition and calculation of government deficit and debt.

Eurostat has a staff of about 800 (in 2005). Of these, 64 are seconded national expert staff. Eurostat's own budget was about 56 million euros, of which 46 million euros were budgeted 
for implementing the Statistical Programme. In addition, a budget of 38 million euros was subdelegated to Eurostat by other directorate-generals.

\section{B. Eurostat's Legal Mandate}

Eurostat's legal mandate is based on three major acts adopted in 1997:

- $\quad$ The Statistical law adopted by the council of the European Union, which defines the division of responsibility between national and Community statistics and also the basic conditions, procedures, and general provisions governing EU official statistics.

- A Commission Decision which clarified the role of Eurostat as the community statistical authority and established the need for those engaged in community statistics to follow fundamental principles in ensuring that statistics are scientifically independent, transparent, impartial, reliable, pertinent, and cost-effective.

- $\quad$ Article 285, which was inserted in the Amsterdam Treaty, and provides Community statistics with a constitutional basis for the first time. It reaffirmed the principles of the Commission Decision along with statistical confidentiality, thus giving Eurostat a legal mandate to conduct its business rather than requiring special agreements for each statistical activity. This gives Eurostat broader powers and more flexibility in carrying out its mission.

The Union Treaty and its protocol in case of the excessive deficit procedure (EDP) confers significant powers to Eurostat when it states that data for the EDP are to be supplied by the Commission. As a directorate-general of the Commission, Eurostat has the full responsibility for the EDP data, which means that data provided by member states can be amended by Eurostat. This strengthens Eurostat's position when entering into dialogues with member states. Much of the success and the pressure for comparable data comes from this legal provision (Glatzel, 2006).

Eurostat's role in the process of setting accounting practices provides a good example of how Eurostat functions within the ESS. Following a sometimes long consultation process, Eurostat concludes the discussion on accounting treatments and publishes the conclusion in a press release. These press releases are regarded by member states as binding guidelines. While a press release is not a legal document, it makes Eurostat's position known and, given Eurostat's role in providing comparable data for the EDP process puts an enforcement mechanism in place. These guidelines have been of significant practical importance in bringing consultations to closure and strengthening the comparability of data across member countries.

While Eurostat has been widely recognized for its important role as a catalyst of regional data for the EU, some shortcomings, particularly of its governance structure are also noteworthy. These criticisms can broadly be summarized as a "accountability deficit" which arises because, unlike national statistical agencies that are accountable to the public through democratic processes, Eurostat is not fully embedded in a system of checks and balances. 
Fellegi and Ryten (2005) point out that being a unit within the European Commission, Eurostat is not subject to parliamentary oversight as national statistical agencies would be in most EU member states. Fellegi and Ryten analyze Eurostat's governance structure and conclude that a more independent organizational framework, more along the lines of a national statistical office, would strengthen the public trust and confidence as well as the quality of the statistics. They propose a set of measures to address these points, including specific legislation establishing the ESS and Eurostat as its chief institutional component, with substantive autonomy and with a broadly defined mandate.

\section{Box 1. The Evolution of Eurostat}

1953: The Statistics Division for the Coal and Steel Community established.

1958: The European Community founded and the forerunner of Eurostat established.

1959: The present name of Eurostat as the Statistical Office of the European Communities adopted. First publication issued — on agricultural statistics.

1960: First Community Labor Force Survey.

1970: The European System of Integrated Economic Accounts (ESA) published and the general industrial classification of economic activities (NACE) established.

1974: First domain in the Cronos databank installed.

1988: European Commission adopts a document defining the first policy for statistical information.

1989: The Statistical Programme Committee (SPC) established and the first program (1989-92) adopted by the Council as an instrument for implementing statistical information policy.

1990: The Council adopts a directive on transmission of confidential data to Eurostat, previously an obstacle to Community statistical work.

1991: Eurostat's role extended as a result of the agreement on establishment of the European Economic Area and adoption of the Maastricht Treaty.

1992: Statistical Programme 1993-97 adopted.

1993: The single market extends Eurostat's activities, including establishment of Intrastat for statistics on intra-EU trade. Eurostat starts issuing regular news releases.

1994: First European household panel held, analyzing income, employment, poverty, social exclusion, households, health, etc.

1997: Statistics added for the first time to the Treaty of Amsterdam and the Statistical Law approved by the Council. Harmonized Indices of Consumer Prices published for the first timedesigned for EMU convergence criteria.

1998: The 11 countries in at the start of EMU (EUR-11) announced and Eurostat issues the first indicators specific to the EMU are. Statistical programme 1998-2002 adopted.

1999: Start of EMU, January 1, 2001. Greece joins euro zone.

2002: Start of the circulation of euro banknotes and coins. Statistical programme 2003-07 adopted. 


\section{Key LeSSONS FOR A FUTURE GULFSTAT}

In many respects, Afristat and Eurostat are very different agencies. Afristat is an agency focused on fostering capacity building and working with statistical agencies that are in the process of development. Its constituency is broadly defined. By contrast, Eurostat evolved in an environment of well-developed national statistical agencies and its functions were defined more narrowly by policy goals of the EU. Gulfstat would combine features of both agencies. Gulfstat would serve a small group of countries and could be highly focused on supporting integration of six countries. On the other hand, Gulfstat would be working with statistical agencies that are in the process of development and hence capacity building should be one of its tasks.

Afristat and Eurostat also have similar features: both coordinate activities of national statistical agencies, promote harmonization of statistical processes and harmonization of methodologies, and, more generally promote the dialogue of statistical agencies. A number of useful lessons for Gulfstat can be derived from these functions.

Data collection from individuals or enterprises is not a core activity of either Afristat or Eurostat. In both, data collection remains mainly the prerogative of national statistical agencies. In the case of Eurostat, this can be explained by the existence of strong national statistical agencies. For the GCC countries, where national statistical agencies are in the process of development, a greater role for the regional agency in data collection should be considered, especially from a viewpoint of what is the most efficient approach. Gulfstat can combine features of both Afristat and Eurostat but it might develop some features that are unique to the environment of GCC regional statistical integration.

\section{A. Coordination Role}

Both Afristat and Eurostat are coordinators and leaders in bringing about harmonization of data standards, and both focus on data dissemination of regional data. Similarly, a key function of a new regional agency, Gulfstat, would be to intensify the collaboration among statistical agencies, to develop common work programs, and to coordinate data collection procedures to support comparability of data and common programs of data dissemination.

In analogy to the ESS, a Gulf System of Statistics (GSS) would appear to be a good format to integrate national statistical agencies and a regional agency. Gulfstat would thus be an integral part of the system rather than an independent agency. Eurostat organizes its collaboration with member countries through active advisory groups within the ESS. These play a crucial role in bringing member countries' statistical practices closer together. The GCC countries already have some advisory groups; thus, expanding their roles in the context of a regional Gulfstat would seem to be an important requirement. The example of the Eurostat CMFB is particularly relevant for the GCC countries, because it is a highly useful forum for getting the various data producers, especially central banks and national statistical offices, to speak to each other and thus to develop integration across a range of macroeconomic statistics. 


\section{B. Roles of National Statistical Offices, including for Government Finance Statistics}

Eurostat's role within the EU and relative to the national statistical agencies is well defined. An important step in fostering collaboration across GCC statistical agencies would be to clearly assign the responsibilities for producing official statistics on the national level, which is not currently the case in all countries. This may entail some streamlining of the currently complex institutional structure. In creating a GCC system of statistics, the national statistical agencies will need to be identified for each country. To allow the agencies to enter into an agreement with Gulfstat, further legal action may be required, especially in cases where the national statistical agency is housed in a ministry.

The involvement of the ministries of finance as responsible for producing government finance statistics would be a special challenge for the GCC countries. Their roles in advisory groups would need to be explicitly included. By contrast, in most European countries, the national statistical agencies have responsibility for disseminating government finance statistics with the assistance of the finance ministries, which provide source data.

Firm agreements among ESS members about dissemination requirements support Eurostat's work, and these are reinforced through their SDDS memberships. Similarly, procedures are in place for reporting data related to the Resolution of the Amsterdam European Council on the Stability and Growth Pact (Amsterdam European Council, 1997). Such contractual relations contain useful lessons for the GCC countries. As a first step, participation in the GDDS could be a vehicle for "comparing notes" on current dissemination practices. GCC countries could use the GDDS recommended standards for timeliness and periodicity as guideposts for converging dissemination practices.

\section{Development of a Legal Framework}

A strong legal framework underpins Eurostat's mission, and its evolution bears important lessons for the governance structure of Gulfstat and for its legal mandates. It is beyond the scope of this paper to lay out the details, but major issues are to clarify the agency's standing within the system of national statistical agencies as playing a coordinatoring role and as having the right to request data needed for regional statistics. Assigning Gulfstat a role in providing the data required for monitoring convergence criteria or fiscal rules could be an effective way to foster comparable accounting practices and harmonization of statistical methods.

Gulfstat should be endowed with a strong governance structure, making it an independent agency with the necessary legal foundation to support professionalism and public trust and confidence in the statistics it publishes. Appropriate oversight and accountability should be given a high priority in setting up Gulfstat. Gulfstat could be embedded in a system of national statistical agencies, similar to the ESS, and this may require harmonizing the governance structures of national statistical agencies. 


\section{Producer of Regional Data}

The heads of national statistical agencies in the GCC countries have already agreed on some coordinated surveys, and Gulfstat could provide the institutional setting for this activity. While data collection remains in the hands of national statistical agencies, in practice, Eurostat is an active partner in this process. Gulfstat could, similarly, play an active role in compiling regional data and this will require significant resources, including staff.

Afristat and Eurostat's constituencies are broad economic areas including but not limited to monetary unions (Table 4). This may contain another lesson, namely, that Gulfstat would have its own merits in supporting development of statistics in the region and thus fostering economic integration of the Gulf States. It would also suggest that a regional statistical agency could proceed at a different pace than the common market and monetary union agendas. This lesson is further supported by the evolution of Eurostat over a long period, recognizing that the preparation of data is a long-term process. Gulfstat would, at the same time, have a highly focused mission, because its membership would be limited to the group of countries currently preparing for a common market and monetary union.

\section{E. Methodological Harmonization}

In some aspects, Afristat's objectives, priorities, and operational modalities are similar to the priorities and objectives of the GCC national statistical agencies, particularly in the fields of national accounts, prices, household surveys, and GDDS practices. The common statistical work under the umbrella of the GCC Secretariat envisages consistency, timeliness, and comparability of statistical data as high priority areas. Work is in progress to adopt a common methodology in preparing national accounts estimates (quarterly GDP at current and constant prices). In this regard, a plan of action with a detailed time frame to implement the 1993 SNA is currently being prepared by the Statistical Committee of the GCC. Also, efforts are underway to finalize unification of statistical definitions, concepts, and classifications. Moreover, methodology of compiling intra-GCC trade statistics is under review with close coordination between statistical offices and customs departments. ${ }^{9}$

\footnotetext{
${ }^{9}$ Progress in all these issues was discussed in the $18^{\text {th }}$ session of the GCC Heads of Statistical Offices, Manama, Bahrain, March 13-14, 2005.
} 
Table 4. Afristat and Eurostat Support Economic Regions beyond Monetary Unions

\begin{tabular}{|c|c|c|c|}
\hline \multirow[t]{2}{*}{$\begin{array}{c}\text { Afristat } 18 \\
\text { Member } \\
\text { Countries }\end{array}$} & $\begin{array}{c}\text { Eight Members of } \\
\text { West African Economic } \\
\text { and Monetary Union } \\
\text { (WAEMU) } *\end{array}$ & $\begin{array}{l}\text { Six Members of } \\
\text { Central African } \\
\text { Economic and } \\
\text { Monetary Union } \\
\text { (CEMAC)* }\end{array}$ & 4 Others \\
\hline & $\begin{array}{c}\text { Benin } \\
\text { Burkina Faso } \\
\text { Côte D’Ivoire } \\
\text { Guinea Bissau } \\
\text { Mali } \\
\text { Niger } \\
\text { Senegal } \\
\text { Togo }\end{array}$ & $\begin{array}{c}\text { Cameroon } \\
\text { Central African } \\
\text { Republic } \\
\text { Chad } \\
\text { Equatorial Guinea } \\
\text { Congo } \\
\text { Gabon }\end{array}$ & $\begin{array}{l}\text { Cape Verde } \\
\text { Comoros } \\
\text { Guinea } \\
\text { Mauritania }\end{array}$ \\
\hline $\begin{array}{c}\text { European } \\
\text { Statistical } \\
\text { System (ESS) }\end{array}$ & \multicolumn{2}{|c|}{25 European Union Countries } & 3 Others \\
\hline \multirow{2}{*}{$\begin{array}{l}\text { Eurostat plus } \\
\text { statistical } \\
\text { agencies of EU } \\
+3 \text { other } \\
\text { countries }\end{array}$} & $\begin{array}{c}12 \text { Euro Area } \\
\text { participating countries }\end{array}$ & $\begin{array}{l}13 \text { Other } \\
\text { European Union } \\
\text { Member States }\end{array}$ & \\
\hline & $\begin{array}{c}\text { Austria } \\
\text { Belgium } \\
\text { Finland } \\
\text { France } \\
\text { Germany } \\
\text { Greece } \\
\text { Ireland } \\
\text { Italy } \\
\text { Luxembourg } \\
\text { The Netherlands } \\
\text { Portugal } \\
\text { Spain }\end{array}$ & $\begin{array}{c}\text { Czech Republic } \\
\text { Cyprus } \\
\text { Denmark } \\
\text { Estonia } \\
\text { Hungary } \\
\text { Latvia } \\
\text { Lithuania } \\
\text { Malta } \\
\text { Poland } \\
\text { Slovakia } \\
\text { Slovenia } \\
\text { Sweden } \\
\text { United Kingdom }\end{array}$ & $\begin{array}{c}\text { Iceland } \\
\text { Norway } \\
\text { Liechtenstein }\end{array}$ \\
\hline
\end{tabular}

Source: Websites of : Afristat, European Union, ECB, WAEMU, and CEMAC.

* CFA Franc Zone.

\section{F. Uniform Dissemination Practices}

Eurostat's work receives implicit support by the fact that most of its constituency subscribes to the SDDS, which entails commitment to timely data dissemination in line with international standards. Afristat's work, as well, benefits from the GDDS membership of its member countries. Universal participation of GCC countries in the GDDS, with a view to moving towards SDDS subscription over time, would lend support to the effectiveness of a regional statistical agency. 


\section{G. Resources Needed for Gulfstat}

Resources required for Gulfstat would ultimately have to be determined in line with the functions of the new central agency. Lessons can be learned from both Afristat and Eurostat. The GCC comprises a group of six countries, while both Afristat and Eurostat have much larger constituencies. Afristat grew out of the need to pool the scarce financial resources of its member countries, whereas the GCC countries do not face such constraints. On the other hand, Afristat provides a good example of how a lean organization staffed with only 12 professionals can serve the diverse needs of its members. Afristat's role in supporting development of national statistical agencies is also similar to the situation of the GCC states.

Eurostat evolved at a time when national statistical agencies were already well developed. In this environment, Eurostat's main role as coordinator of statistical activity was a natural outgrowth. For Gulfstat, the environment would be different as national statistical agencies are in the process of development and Gulfstat could play an important role in leading this process. In general terms, given the number of countries involved, Gulfstat would need to consider a staff closer to that of Afristat (12) than of Eurostat (about 800). Gulfstat could consider employing a mix of own staff and staff seconded from national statistical agencies as a way to foster collaboration and integration.

In considering the resources needed for Gulfstat and for building a regional statistical system, some of the potential risks must be adequately considered. Clearly, building a regional statistical system will initially increase the overall resources required to produce adequate statistics, as additional (regional and national) data are produced and as national statistical agencies adjust their statistical practices. Gulfstat would need to remain mindful of these increased responsibilities and should take an active role in fostering efficiency and avoiding duplications.

\section{H. Technical Assistance Center}

Another useful lesson from Afristat could be its technical assistance function to member institutions. While Eurostat does not have such a function within the ESS, many of its staff are experts seconded from member statistical agencies - another way of drawing on specialized expertise and building regional coherence. Gulfstat may seek to employ a mix of both, employing some international experts and drawing on some staff from regional statistical agencies. Gulfstat could play a role in organizing training courses for the national statistical agencies.

\section{CONCLUSIONS}

Afristat and Eurostat each offer relevant insights for the future development of statistics for the region of the GCC member states. In both instances, important functions were to develop and then implement common action plans and strategic frameworks for the development of statistics. The strategic framework is the basis of harmonization and the comparability of statistics within a specified time frame. Both agencies were formed to help provide comparable statistics for an economic region, and supporting functions for monetary union 
were, or became, key aspects of this. However, both agencies' mandates go far beyond the support of monetary union and serve to foster economic integration.

Against the background of this experience, a regional statistical agency could serve the GCC countries well in their endeavor to move towards a common market and monetary union. A GCC regional statistical agency could combine elements from both Eurostat and Afristat as outlined in the previous section. With the GCC national statistical offices still evolving, the need for developing common methodology for collecting and processing certain data is of overriding importance, along with a program of data dissemination. In building Gulfstat, its potential role as compiler of statistics should be given special consideration. Contrary to Eurostat, which evolved in the midst of fully developed national statistical agencies, Gulfstat would be part of the process of building strong national statistical agencies. Efficiency gains in centralizing some data collection activities could well be realized in this way.

One of Gulfstat's initial tasks could be coordination of the collection of price statistics for the International Comparison Program (ICP). All GCC countries participate in the program, and it adopts a common methodology in data collection. A case may be put forward for a central agency, Gulfstat, to undertake this task. Another, equally important area is adoption of national accounts methodology (1993 SNA), which requires a unified implementation approach. A third case is the construction of export and import indices and treatment of intraGCC trade statistics (exports and re-exports). Finally, a key dimension to GCC cooperation is capacity building, where Gulfstat could be given responsibility for organizing training for statisticians in the region. This would appear to be a cost-effective approach for creating national expertise and creating a coherent and consistent environment for statistical work in the GCC countries.

In setting up a new regional statistical agency, a number of more specialized issues are to be considered. These are, particularly, the appropriate governance structure, including the legal framework; modalities of financing a regional statistical agency; and the linkages to the national statistical agencies. Given the relatively large number of national statistical agencies, some streamlining of institutional frameworks may also be considered. Special provisions may be needed for national statistical agencies that are part of national ministries. 
Table A.1. Gulf Cooperation Council States-Selected Economic Indicators

\begin{tabular}{|c|c|c|c|c|c|c|c|}
\hline & $\begin{array}{r}\text { Real GD } \\
\text { Annual C } \\
\text { per }\end{array}$ & $\begin{array}{l}\text { Growth } \\
\text { ange, in } \\
\text { nt }\end{array}$ & $\begin{array}{l}\text { Consun } \\
\text { In }\end{array}$ & Price & Oil & Gas & Population \\
\hline & $\begin{array}{c}1998- \\
2002 \\
\text { Average }\end{array}$ & 2005 & $\begin{array}{c}1998- \\
2002 \\
\text { Average }\end{array}$ & 2005 & $\begin{array}{l}\text { Proven } \\
\text { reserves } \\
\text { in billion } \\
\text { barrels } \\
\end{array}$ & $\begin{array}{c}\text { Proven } \\
\text { reserves in } \\
\text { trillion } \\
\text { cubic meters }\end{array}$ & $\begin{array}{c}2004 \\
\text { (In millions) }\end{array}$ \\
\hline Bahrain & 4.8 & 7.1 & -0.8 & 3.7 & 0.1 & 0.1 & .72 \\
\hline Kuwait & 0.8 & 3.2 & 1.5 & 1.8 & 99.0 & 1.6 & 2.61 \\
\hline Oman & 3.6 & 3.8 & 0.3 & 1.9 & 5.6 & 1.0 & 2.53 \\
\hline Qatar & 7.4 & 5.5 & 1.8 & 3.0 & 15.2 & 25.8 & .78 \\
\hline Saudi Arabia & 1.5 & 6.0 & -0.5 & 1.0 & 262.7 & 6.8 & 23.95 \\
\hline UAE & 4.0 & 7.5 & 2.2 & 6.0 & 97.8 & 6.1 & 4.28 \\
\hline
\end{tabular}




\section{REFERENCES}

Afristat, 2001, "Contribution to Statistical Capacity Building in Member States During the 1996-2000 Period," Seminar on the Launching of the Study: "Afristat After 2005," 7-9 May, 2001, Bamako, available on the web at http://www.Afristat.org.

Afristat, 2005, “Les Orientations Strategiques de Travail de la Direction Generale D'Afristat Pour la Periode 2006-2010, Bamako, March 2005, available on the web at http://www.Afristat.org.

Amsterdam European Council, 1997, "Resolution of the European Council on the Stability and Growth Pact," Official Journal, C 236.

Astin, John, 1999, "The European Union Harmonised Indices of Consumer Prices (HICP)," Statistical Journal of the United Nations, Economic Commission for Europe, Vol. 16, Nos. 2-3, 1999.

BP Statistical Review of World Energy, June 2005, pg. 20, available on the web at http://www.bp.com/sectiongenericarticle.do? categoryId $=9003066 \&$ contentId $=700590$.

Bull, Peter, 2004, The Development of Statistics for Economic and Monetary Union, Frankfurt: European Central Bank, 2004.

Cady, John, 2004, "Does SDDS Subscription Reduce Borrowing Costs for Emerging Market Economies," IMF Working Paper 04/58 (Washington: International Monetary Fund).

— Reports Versus International Financial Statistics” IMF Working Paper 05/46 (Washington: International Monetary Fund).

Carson, Carol S., and Lucie Laliberté, “Assessing Accuracy and Reliability: A Note Based on Approaches Used in National Accounts and Balance of Payments Statistics" IMF Working Paper 02/24 (Washington: International Monetary Fund).

— to Guide Future Work," Statistical Journal of the United Nations, ECE 19, pp. 24359.

, Sarmad Khawaja, and Thomas K. Morrison, 2004, "Revisions Policy for Official Statistics: A Matter of Governance," IMF Working Paper 05/98 (Washington: International Monetary Fund).

Data Quality Assessment Framework (DQAF), available on the web at http://dsbb.imf.org (go to Data Quality Reference Site DQRS). 
Dziobek, Claudia, and Mei Jin, 2002, "The Role of Monthly Economic Statistical Bulletins" IMF Policy Discussion Paper 02/9 (Washington: International Monetary Fund).

Eurostat official website, http://epp.eurostat.cec.eu

European Commission, Eurostat, and European Central Bank, 2003, "Memorandum of Understanding on Economic and Financial Statistics," Brussels, March 2003, available on the web at http://www.ecb.int/.

Fasano, Ugo, and Zubair Iqbal, 2002: Common Currency, Finance \& Development, Vol. 39, December.

Fellegi, Ivan, and Jacob Ryten, 2005, “The Effectiveness of a Supranational Statistical Office. Pluses, Minuses, and Challenges Viewed from the Outside," Journal of Official Statistics, Vol. 21, No. 2.

, 1996, "Characteristics of an Effective Statistical System," International Statistical Review, Vol. 64, No. 2.

Glatzel, Dieter, Implementing the Fiscal Rules: Checking and Validating National Data, Eurostat Directorate Economic and Monetary Studies, 2006 (forthcoming).

Gulf Cooperation Council (GCC), 1981, Foundation and Objectives, available on the web at http://www.gcc-sg.org.

International Monetary Fund, 2002, Supplement to the 2002 Government Finance Statistics Yearbook, Illustrating the Use of the Government Finance Statistics Manual 2001 Framework for Countries with Different Fiscal Accounting Systems (Washington).

International Monetary Fund, 2003, Monetary Union Among Member Countries of the Gulf Cooperation Council, IMF Occasional Paper No. 223, (Washington: International Monetary Fund).

International Monetary Fund, 2004, "Managing Director Rodrigo de Rato Underscores Strengthening Economic Cooperation Among the Gulf Cooperation Council (GCC) Countries," IMF Press Release No. 04/222, October 23.

International Monetary Fund, 2005, "Middle East and Central Asia Regional Economic Outlook," September 2005.

Jadresic, Esteban, 2002, “On a Common Currency for the GCC Countries," IMF Policy Discussion Paper 01/12, (Washington: International Monetary Fund). 
Khawaja, Sarmad, and Thomas K. Morrison, 2002, "Statistical Legislation: Toward a More General Framework," IMF Working Paper 02/179 (Washington: International Monetary Fund).

Krueger, R., and Ettore Kovarich, 2006, "Some Principles for Development of Statistics for a GCC Currency Union," (forthcoming as an IMF Working Paper.)

Kuwait, Statistics and Census Sector (SCS), Ministry of Planning, 2004, "Vision of 2005 Joint Statistical Work Program in the GCC," (unpublished Memorandum).

Ocampos, Lorraine, "Regional Issues in Macroeconomic Statistics," in Rodlauer, Markus and Alfred Schipke, eds., 2005, Central America: Global Integration and Regional Cooperation, IMF Occasional Paper No. 243 (Washington: International Monetary Fund).

ROSC data Module, Report on the Observance of Standards and Codes (ROSC), Data Module. IMF Staff Country Reports are available on the web at http://www.imf.org/external/np/rosc/rosc.asp.

United Nations, 1994, "United Nations Fundamental Principles," available on the web at http://unstats.un.org/unsd/goodprac/bpabout.asp.

United Nations, Statistics Division, 2003, Handbook of Statistical Organization: on the Operation and Organization of a Statistical Agency, $3{ }^{\text {rd }}$ edition (New York).

Zieschang, Kimberly, “A Framework for Price Statistics,” IMF Working Paper 00/24 (Washington: International Monetary Fund). 